Journal of Applied Pharmaceutical Science Vol. 8 (01), pp. 001-008, January, 2018

Available online at http://www.japsonline.com

DOI: $10.7324 /$ JAPS.2018.8101

ISSN 2231-3354 (cc) BY-NC-SA

\title{
The Anti-dyslipidemic Effects of Milled Root Bark Ethanolic Extract of Capparis erythrocarpus in Sprague-Dawley Rats: Implications for Obesity and Cardiovascular Diseases
}

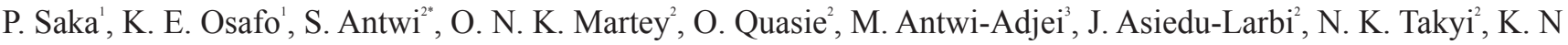 \\ Donkor $^{2}$, L. K. N. Okine \\ 'Department of Biochemistry, Cell \& Molecular Biology, University of Ghana, Legon, Accra, Ghana. \\ ²Department of Pharmacology/Toxicology, Centre for Plant Medicine Research, Mampong-Akuapem, Ghana. \\ ${ }^{3}$ Department of Pharmacology, School of Medical Sciences, University of Cape Coast, Cape Coast, Ghana.
}

\begin{tabular}{|c|c|}
\hline ARTICLE INFO & ABSTRACT \\
\hline $\begin{array}{l}\text { Article history: } \\
\text { Received on: } 13 / 08 / 2017 \\
\text { Accepted on: } 11 / 12 / 2017 \\
\text { Available online: } 28 / 01 / 2018\end{array}$ & $\begin{array}{l}\text { Dyslipidaemia is a major risk factor of the onset of cardiovascular disease and obesity. Sirappac, the milled root bark } \\
\text { of C. erythrocarpus has been reported to significantly reduce body weight and sizes of Sprague-Dawley rats with } \\
\text { possible effects on the alteration of lipid metabolism. The present study was thus, aimed at determining the effects of } \\
\text { sirappac on the body weight, food intake, serum lipid levels and blood pressures in rats. Male adult Sprague-Dawley } \\
\text { rats were treated with sirappac at doses of } 20,100 \text { and } 200 \mathrm{mg} / \mathrm{kg} \text { for a period of three months. Rats body weight and }\end{array}$ \\
\hline $\begin{array}{l}\text { Key words: } \\
\text { Dyslipidaemia, cardiovas- } \\
\text { cular disease, obesity, } C \text {. } \\
\text { erythrocarpus }\end{array}$ & $\begin{array}{l}\text { lesterol (HDLC), low density lipoprotein-cholesterol (LDLC) and leptin levels were determined monthly throughout } \\
\text { the study period. At the end of the treatment period, there were significant }(\mathrm{p}<0.05) \text { dose-dependent reductions in } \\
\text { body weight, food intake, serum levels of TC, LDLC, TG and serum leptin. However, the levels of HDLC increased } \\
\text { significantly }(\mathrm{p}<0.05) \text { over the study period. Sirappac also significantly }(\mathrm{p}<0.05) \text { reduced rat systolic blood pressure } \\
\text { without effect on the diastolic blood pressure. The results indicate that sirappac exerts anti-lipidaemic effects and could } \\
\text { be indicated in management of cardiovascular diseases, whilst preventing obesity by reducing feed intake and the rate } \\
\text { of increase in body weight in Sprague-Dawley rats. }\end{array}$ \\
\hline
\end{tabular}

\section{INTRODUCTION}

Cardiovascular diseases are a major cause of death in both developed and developing countries. Dyslipidaemia is one of the major risk factors that leads to the development of this disease and is frequently associated with obesity, diabetes mellitus and hypertension (Mahalle et al., 2014). Dyslipidaemia is characterized by abnormally high levels of serum total cholesterol (TC), triglycerides (TG) and low density lipoprotein-cholesterol (LDLC), and low levels of high density lipoprotein-cholesterol (HDLC).

Although a change in lifestyle is useful for lowering increased lipid levels, orthodox drugs are also available to con-

${ }^{*}$ Corresponding Author

S. Antwi, Department of Pharmacology/Toxicology, Centre for Plant

Medicine Research, P. O. Box 73, Mampong-Akuapem, Ghana.

E-mail:stephen.antwi@cpmr.gov.gh trol elevated forms of lipids in patients with dyslipidaemia. These lipid-lowering drugs are classified into two major groups called statins and fibrates. Statins are known to lower cholesterol by interfering with the cholesterol biosynthesis pathway (Krukemyer and Talbert, 1987; Hebert et al., 1997) whiles fibrates decrease fatty acid and triglycerides by stimulating the peroximal-oxidation pathway (Reddy et al., 1986; Watts and Dimmitt, 1999; Asztalos et al., 2002; Steinmetz, 2002; Ozawa and Ozawa, 2002). There are other lipid lowering drugs that are used by clinicians such as acylCoA: cholesterol acyltransferase (ACAT) inhibitors (Kharbanda et al., 2005), Microsomal triglyceride transfer proteins (Ueshima et al., 2005), cholesteryl ester transfer proteins (Gauthier et al., 2005), niacin, omega-3 fatty acids and bile acid resins (Vasudevan and Jones, 2005).

There has been serious concern on the long term usage of some of these drugs as well as their high costs, which are beyond 
the purchasing power of most people in developing countries. Indeed, about $80 \%$ of rural populations in these countries depend on traditional medicine, including herbal medicines for their primary healthcare needs. Hence, the need to explore the use of some medicinal plants as alternatives for similar pharmacological effect is of essence.

Sirappac is a milled root bark of C. erythrocarpus (Cappariceae), used for the treatment of arthritis at the clinic of the Centre for Plant Medicine Research (CPMR), Mampong-Akuapem, Ghana. Its clinical use is supported by its anti-arthritic effect in Freund adjuvant-induced arthritic Sprague-Dawley rats (SDRs) (Danquah et al., 2011). Caper, a common name of the genus Cap-

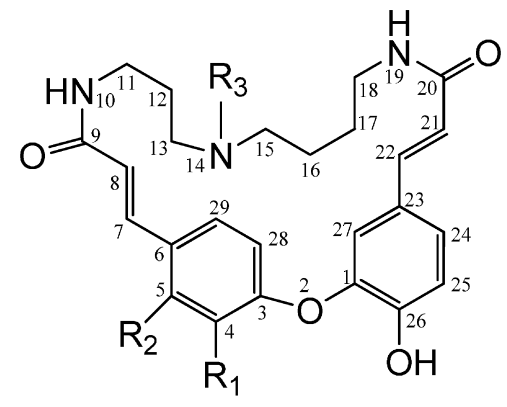

1, $\mathrm{R}_{1}=\mathrm{CH}_{3}-\mathrm{O}-, \mathrm{R}_{\mathbf{2}}=\mathrm{R}_{3}=\mathrm{H}$

2, $\mathrm{R}_{1}=\mathrm{CH}_{3}-\mathrm{O}-, \mathrm{R}_{2}=\mathrm{H}, \mathrm{R}_{3}=\mathrm{CH}_{3}-\mathrm{CO}-$

$3, \mathrm{R}_{1}=\mathrm{H}, \mathrm{R}_{2}=\mathrm{CH}_{3}-\mathrm{O}-, \mathrm{R}_{3}=\mathrm{CH}_{3}-\mathrm{CO}-$ paris and family Capparidaceae are perennial shrubs with over 650 species, and only a few being cultivated (Hutchson, 1967). Several phytochemicals including spermidine, rutin, quercetin, kaempferol, stigmasterol, campesterol, tocopherols, and carotenoids have been shown to be present in the Capparis genus (Tlili et al., 2011). A number of chemicals have been isolated from the roots of members of this genus including (1) isocodonocarpine, (2) 14-Nacetylisocodonocarpine, (3) 15-N-acetylcap- parisine (Viqar Uddin et al., 1992; Viqar Uddin et al., 1989), (4) Capparispine, (5) capparispine 26-O- $\beta$-D-glucoside and (6) cadabicine 26-O- $\beta$ D- glucoside hydrochloride (Fu et al., 2008).

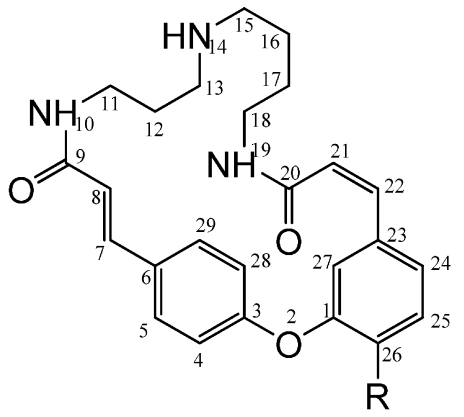

\section{$4, \mathrm{R}=\mathrm{OH}$}

$5, R=O-\beta-D$-glucose

$6, R=O-\beta-D-$ glucose hydrochloride

Fig. 1: Structures of compound 1-6 isolated from the roots of Capparis.

The total herb of $C$. erythrocarpus has been found in a recent study to treat most HIV/AIDS opportunistic infections in Tanzania (Lyaruu et al., 2007). A chronic toxicity study of sirappac in male adult SDRs (Martey et al., 2013) showed significant reductions in body weight gain and feed intake in the $C$. erythrocarpus treated-rats but did not cause any organ specific toxicity. It is unclear whether the reduction in body weight is as a result of loss of appetite or a reduction in gastrointestinal uptake of nutrients or lipid metabolism with the consequent effect on the nutritional status of the animals. This can affect serum levels of major nutrients such as proteins, carbohydrates and particularly lipids. This effect exhibited by C. erythrocarpus may prove beneficial to obese persons and thus, prevent dyslipidaemia, a risk factor associated with cardiovascular diseases such as hypertension.

The aim of the present study was, therefore, to determine the effects of sirappac on the food-intake and body weight as well as on serum levels of leptin and of atherogenic and non-atherogenic lipids associated with cardiovascular diseases, and the attendant effects on the blood pressures in SDRs.

\section{MATERIALS AND METHODS}

\section{Chemicals and reagents}

Test kits: TC, TG and HDLC and LDLC were obtained from ELI Tech (France). Serum Leptin ELISA (EIA) kit was obtained from Crystal Chem Inc. (USA).

\section{Animals}

Male adult SDRs (200-250 g) were obtained from the Animal Experimentation Unit, Centre for Plant Medicine Research (CPMR), Mampong-Akuapem, Ghana and fed with animal feed obtained from the Ghana Agro Food Company (GAFCO), Tema, Ghana. The animals were allowed free access to sterilized distilled water. The animals were handled ethically in accordance with National Institute of Health Guidelines for the Care and Use of Laboratory Animals (NIH Publication no. 85-23, revised in 1985). In addition, all experiments were approved by the Ethics Committee of Centre for Plant Medicine Research (CPMR/PT/201512/004).

\section{METHODS}

\section{Preparation of sirappac powdered extract}

The root bark of the shrub C. erythrocarpus was authenticated and obtained from the Plant Development Department of CPMR, air-dried and milled, after which $1 \mathrm{~kg}$ of the milled raw material was macerated in $5 \mathrm{~L}$ of $70 \%$ ethanol for $72 \mathrm{~h}$. The ethanol was evaporated in a rotary evaporator (EYELA, Shanghai, China) and the aqueous concentrated extract resulting was freezedried to obtain the powdered hydro-ethanolic extract. This extract was packaged and stored at room temperature in a desiccator and suspended in water before administration in experiments.

\section{Treatment of animals}

Four groups $(\mathrm{n}=6)$ of male SDRs $(200-250 \mathrm{~g})$ were each kept in separate metabolic cages $(34 \mathrm{~cm} \times 57 \mathrm{~cm} \times 40$ 
$\mathrm{cm})$. Group I served as the control and received normal feed without sirappac while groups II, III and IV were given normal feed with daily oral administration of sirappac at dosages of 20,100 and $200 \mathrm{mg} / \mathrm{kg}$ of body weight, respectively, representing the therapeutic dose, $5 \times$ and $10 \times$ the therapeutic dose. The method of administration was via oral gavage for three months. All animals received sterilized distilled water ad libitum.

\section{Blood sampling}

Blood samples from all rats in each group were collected by tail bleeding into Eppendorf tubes before the start of drug administration i.e. at baseline, and then monthly afterwards till the end of the study (third month). The blood was allowed to clot and then centrifuged at $4000 \times \mathrm{g}$ for $5 \mathrm{~min}$ in a Densley BS 400 ultracentrifuge. The supernatants obtained as serum samples were subsequently stored at $-40^{\circ} \mathrm{C}$ for further analyses.

\section{Atherogenic indices}

Serum TC, TG, HDLC and LDLC and leptin levels of rats were determined by following the Manufacturer's Assay kit Protocols (ELITech Clinical System, Sees, France) with a fully-automated blood chemistry analyser (ILab 300 Plus, Clinical Chemistry System). Atherogenic indices were calculated as follows:

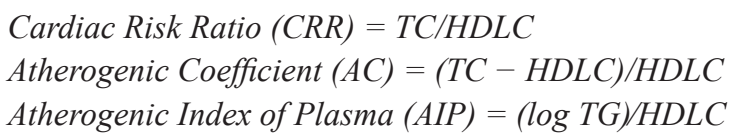

a

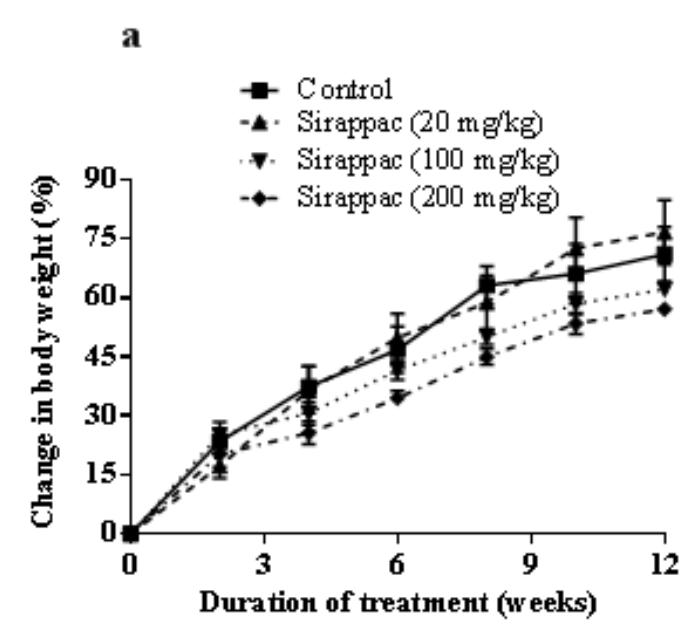

\section{Blood pressure determination}

At the end of the study, the blood pressures of the control and sirappac-treated rats were determined with a 58500 blood pressure recorder (Ugo Basile, Comerio, VA, Italy). Prior to this, the rats were trained for seven days before the readings were taken. Thereafter the readings were taken and the averages calculated and recorded.

\section{Analysis of data}

One-way variance (ANOVA) followed by Newman-Keul's post hoc test was conducted to determine statistical significance. All graphs and area under curves (AUCs) calculated as arbitrary units were prepared using GraphPad Prism for windows software version 6.0 (GraphPad Software, San Diego, CA, USA). P $<0.05$ between treatments was considered statistically significant.

\section{RESULTS}

\section{Body weights}

The mean percentage change in body weights of sirappac-treated rats and the area under curves (AUC) are shown in Fig. 2[a, b] respectively. From the diagrams it is evident that the sirappac-treated animals showed lower changes in body weight with time when compared to the control. The reduction in body weight of the sirappac-treated animals was also dose-dependent with the 100 and $200 \mathrm{mg} / \mathrm{kg}$ sirappac groups showing significant $(\mathrm{p}<0.05)$ reductions in body weights when compared to the control. b

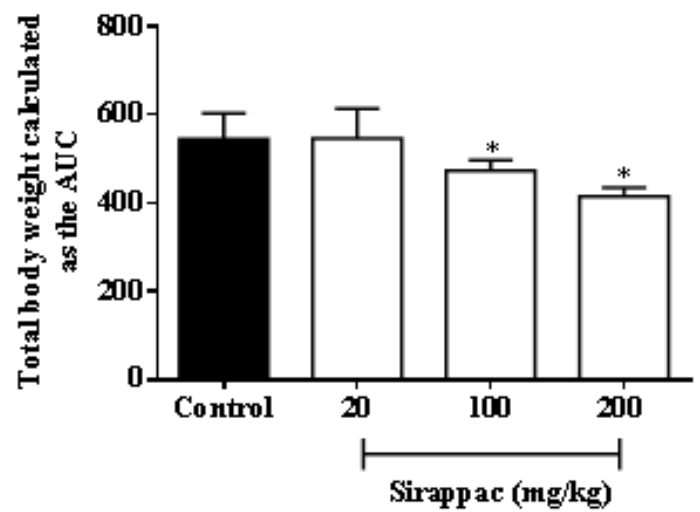

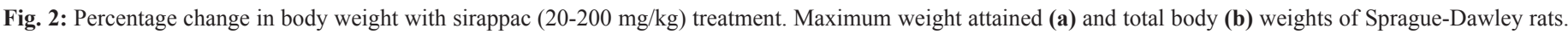
Baseline body weight of animals was $190 \pm 2.54 \mathrm{~g}$. Results are means \pm SEM of $\mathrm{n}=6$. * Value significantly different from control; $\mathrm{p}<0.05$.

\section{Feed intake}

Figure $3[\mathrm{a}, \mathrm{b}]$ shows the mean percentage change in feed intake of sirappac-treated rats and control with their respec- tive AUCs. The results showed dose-dependent reductions in feed intake of sirappac-treated rats when compared to control. These reductions were significant $(\mathrm{p}<0.05$ ) at the dose of $200 \mathrm{mg} / \mathrm{kg}$ of sirappac from the $10^{\text {th }}$ week of treatment and thereafter. 
a

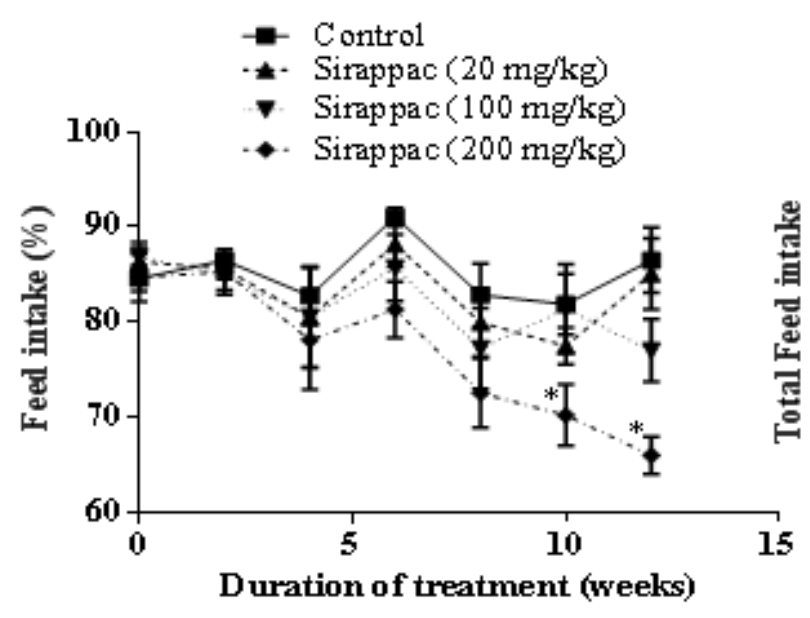

b

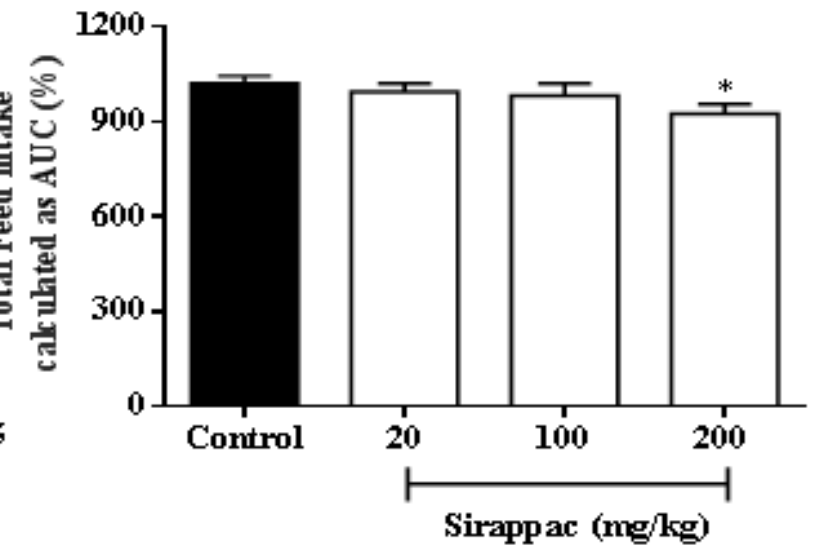

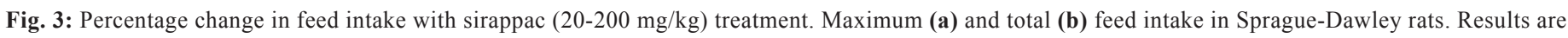
means \pm SEM of $n=6$. *Value significantly different from control; $\mathrm{p}<0.05$.

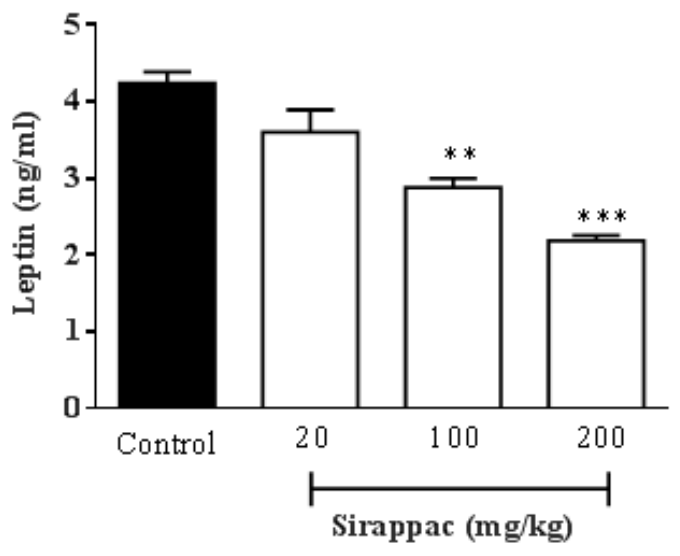

Fig. 4: Leptin concentration with sirappac $(20-200 \mathrm{mg} / \mathrm{kg})$ treatment in Sprague-Dawley rats. Results are means \pm SEM of $\mathrm{n}=6$. ** $(\mathrm{P}<0.01)$, *** $(\mathrm{P}<0.001)$ denote values significantly different from control.

\section{Leptin concentration}

Figure 4 shows the serum concentration of leptin in rats at termination of treatment with sirappac. There were dose-dependent reductions in serum concentration of leptin with significant reductions at 100 and $200 \mathrm{mg} / \mathrm{kg}$ dosages of sirappac $(\mathrm{p}<0.05)$.

\section{Serum total cholesterol}

The effects of sirappac $\left(20-200 \mathrm{mg} \mathrm{kg}^{-1}\right)$ on serum TC levels of experimental animals with duration of treatment and the AUC are shown in Fig. 5 [a, b], respectively. There was a significant dose-dependent reduction $(\mathrm{p}<0.05)$ in TC levels of the sirappac-treatment groups $(20-200 \mathrm{mg} / \mathrm{kg})$ when compared to control after a month of administration.

\section{Serum triglyceride}

Figure $6[\mathrm{a}, \mathrm{b}]$ shows the effects of sirappac $(20-200 \mathrm{mg} /$ $\mathrm{kg}$ ) on serum TG levels of rats with duration of treatment and the AUCs, respectively. There was significant dose-dependent reduction $(\mathrm{p}<0.05)$ in TG levels of the sirappac-treatment groups (20-200 mg/kg), when compared to the control after a month of administration.

\section{Serum HDL-/LDL-Cholesterol}

The effects of sirappac $(20-200 \mathrm{mg} / \mathrm{kg})$ on serum HDLC and LDLC levels of experimental animals are shown in Figs. 7 and 8 , respectively. Figs. $7 \mathrm{a}$ and $8 \mathrm{a}$ represent the effect with duration of treatment whilst Figs. $6 \mathrm{~b}$ and $7 \mathrm{~b}$ represent the AUCs. There were significant dose-dependent increases $(p<0.05)$ in HDLC levels of the sirappac-treatment groups $(20-200 \mathrm{mg} / \mathrm{kg})$ when compared to the control group after a month of administration whilst the reverse was true for LDLC levels.

\section{Atherogenic index}

Figs. 9 represent the time-course effect of treatment on the atherogenic index (a), atherogenic coefficient (b) and the cardiac ratio (c), the total atherogenic index (d), atherogenic coefficient (e) and cardiac ratio (f), respectively represented as AUCs. There were significant dose-dependent reductions $(\mathrm{p}<0.05)$ in all atherogenic indices of the sirappac-treated groups when compared to the control. 
$\mathbf{a}$

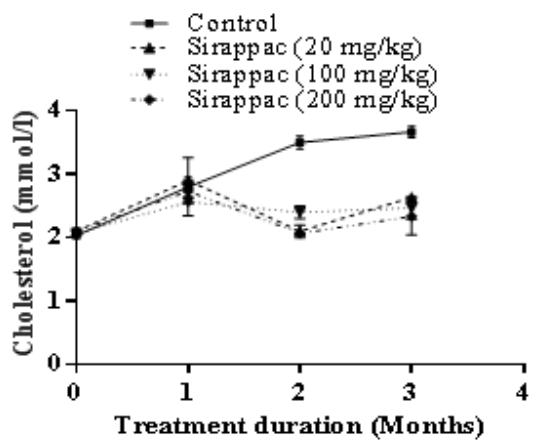

b

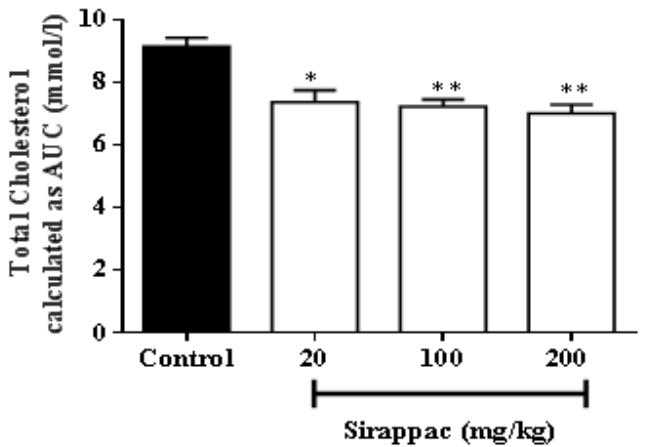

Fig. 5: The effects of sirappac (20-200 mg/kg) on serum TC levels in Sprague-Dawley rats (a) and area under the curve calculated as abitrary units (b). Results are means $\pm \mathrm{SEM}$ of $\mathrm{n}=6 . *(\mathrm{P}<0.05), * *(\mathrm{P}<0.01)$ denote values significantly different from control.

a

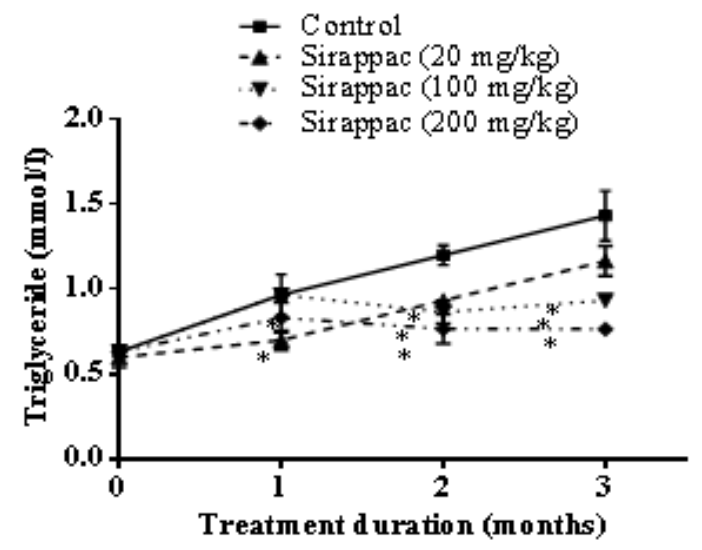

b

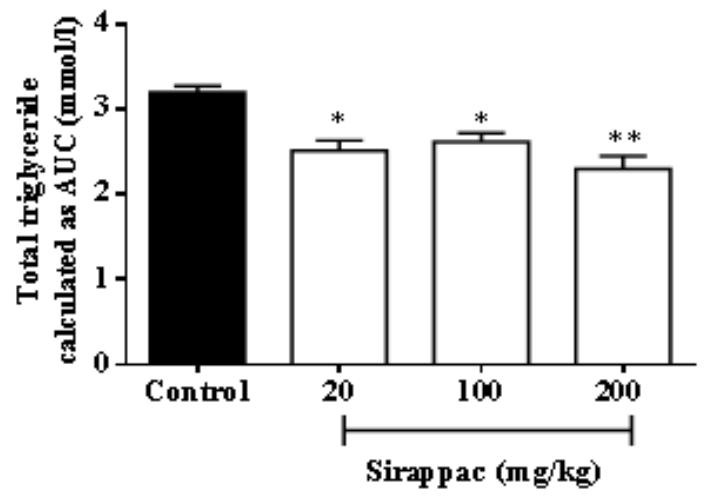

Fig. 6: The effects of sirappac (20-200 mg/kg) on serum TG levels in Sprague-Dawley rats (a) and area under the curve calculated as abitrary units (b). Results are means \pm SEM of $\mathrm{n}=6 . *(\mathrm{P}<0.05), * *(\mathrm{P}<0.01)$ denote values significantly different from control.

a

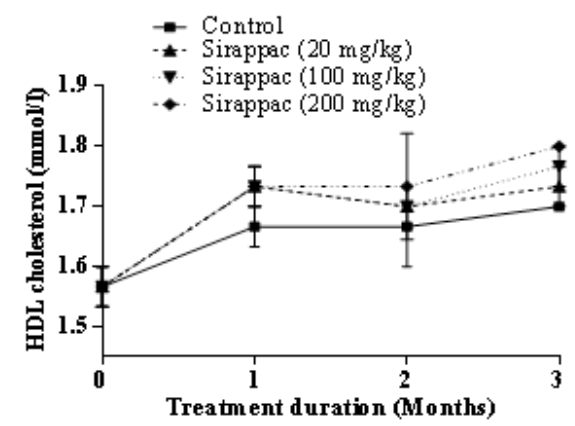

b

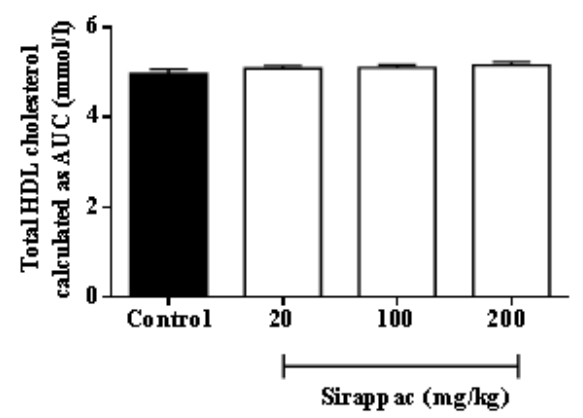

Fig. 7: The effects of sirappac (20-200 mg/kg) on serum HDLC levels in Sprague-Dawley rats (a) and area under the curve calculated as abitrary units (b). Results are means \pm SEM of $n=6$. 


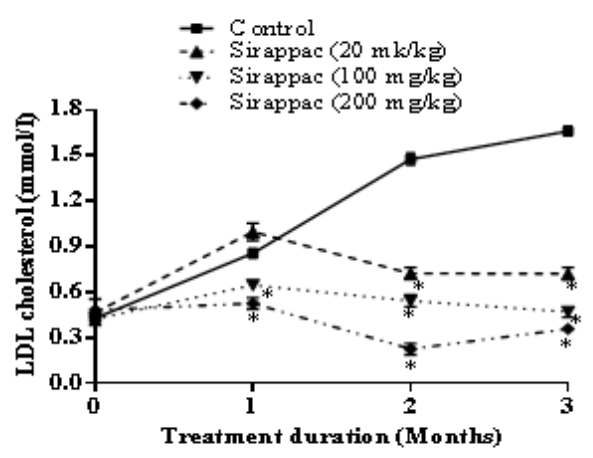

b

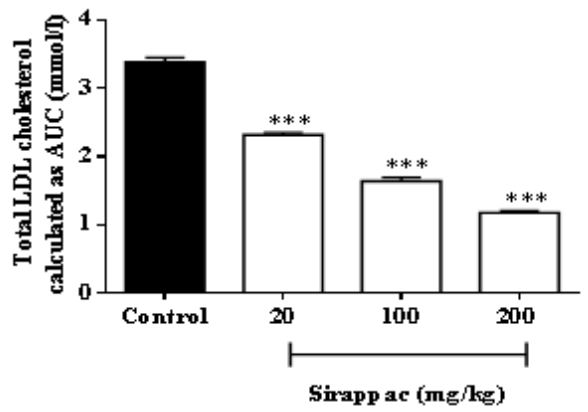

Fig. 8: The effects of sirappac (20-200 mg/kg) on serum LDLC levels in Sprague-Dawley rats (a) and area under the curve calculated as abitrary units (b). Results are means \pm SEM of $\mathrm{n}=6 . *(\mathrm{P}<0.05),{ }^{* * *}(\mathrm{P}<0.001)$ denote values significantly different from control.

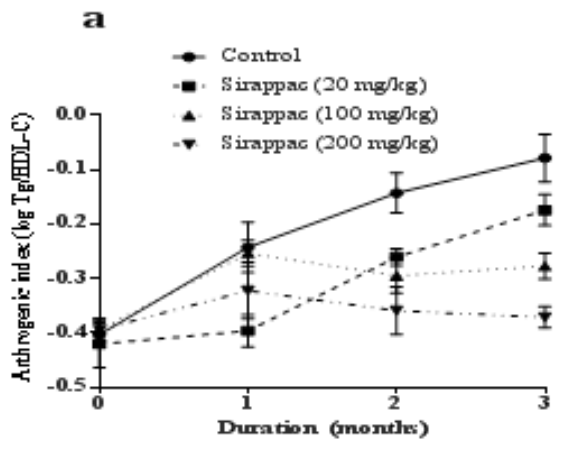

$\mathbf{b}$

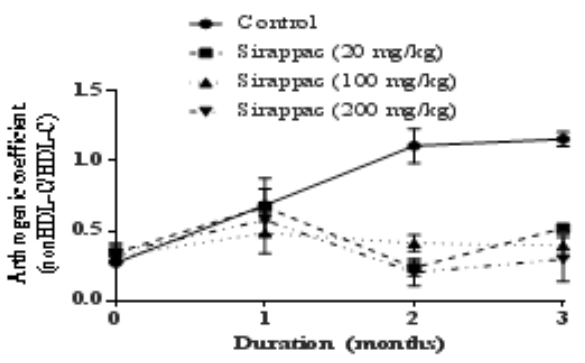

c

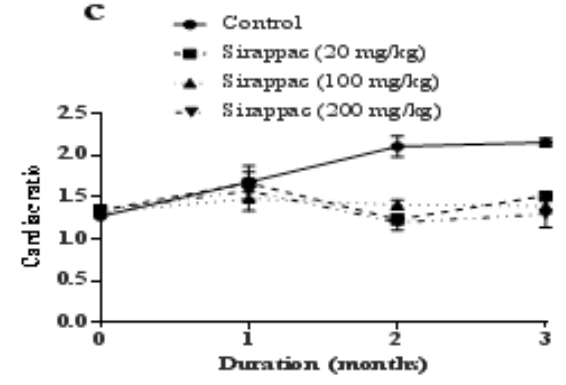

d

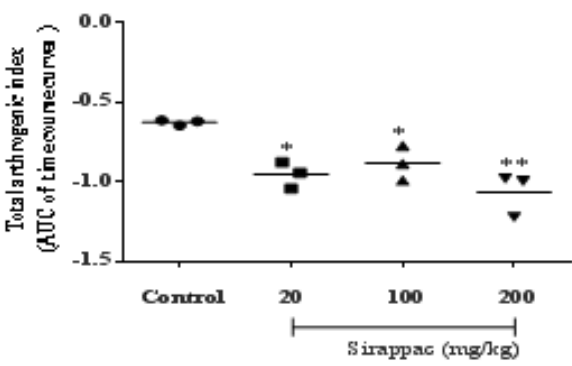

$\mathbf{e}$

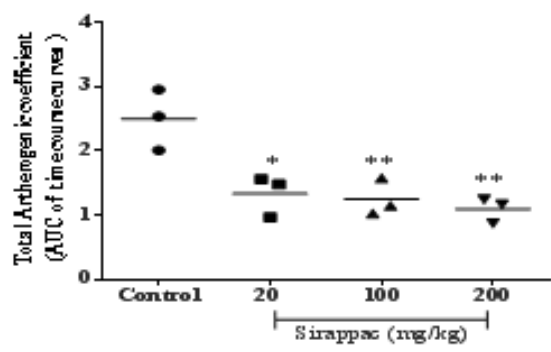

$\mathbf{f}$

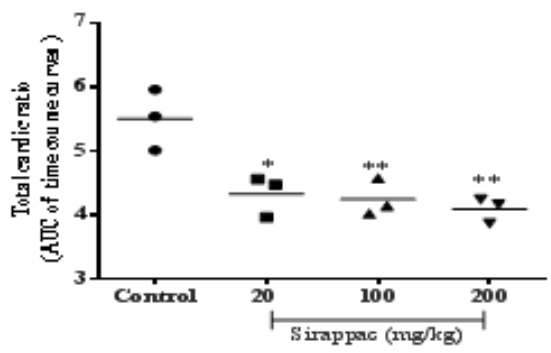

Fig. 9: The effects of sirappac $(20-200 \mathrm{mg} / \mathrm{kg})$ on atherogenic indices. Fig. $9[\mathrm{a}, \mathrm{b}$ and c] represent the time course effect of treatment on atherogenic index, atherogenic coefficient and cardiac ratio respectively and Fig. $9[\mathrm{~d}$, e and f] represent the total atherogenic index, atherogenic coefficient and cardiac ratio respectively calculated as AUC. Results are means \pm SEM of $n=3$. "Values significantly different from control; $\mathrm{p}<0.05$. ${ }^{* *}$ Values significantly different from control; $\mathrm{p}<0.001$. 


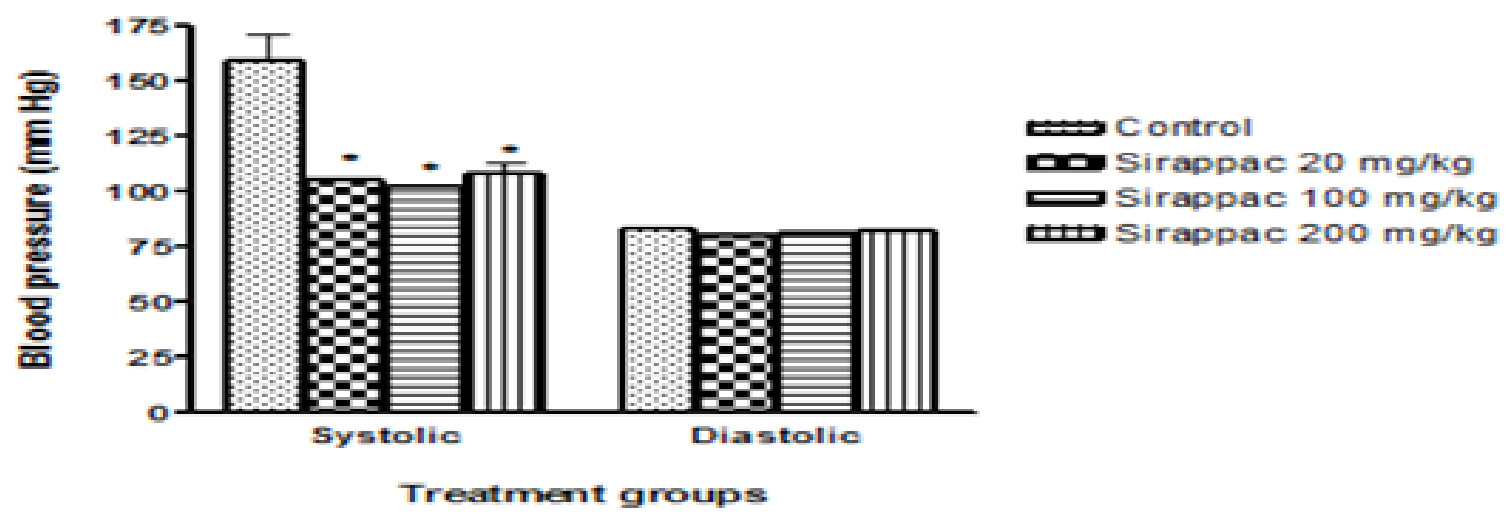

Fig. 10: The effects of sirappac $(20-200 \mathrm{mg} / \mathrm{kg})$ on blood pressure of experimental rats after three months of administration. Results are means \pm SEM $(\mathrm{n}=6) .{ }^{*}$ Values significantly different from control; $\mathrm{p}<0.05$.

\section{Blood pressure}

Figure 10 shows the effects of sirappac (20-200 mg/ $\mathrm{kg}$ ) on the systolic and diastolic blood pressures of SDRs after treatment. There were significant reductions in the systolic blood pressure of the sirappac-treatment groups $(20-200 \mathrm{mg} / \mathrm{kg})$ as compared to the control at the termination of treatment, whereas no significant changes were observed in the diastolic blood pressure.

\section{DISCUSSION}

The present study was conducted to determine the possible mechanism by which sirappac reduces body weight in rats as reported by Martey et al., (2013) through either effects on food-intake or serum leptin levels, or the consequent effects on atherogenic and non-atherogenic lipids known to play significant roles in cardiovascular diseases especially in obese persons.

Results showed a dose dependent reduction in body weight of sirappac-treated rats (Fig. 2) with the $100 \mathrm{mg} / \mathrm{kg}$ and $200 \mathrm{mg} / \mathrm{kg}$ sirappac treatment groups being significantly different $(\mathrm{p}<0.05)$ from the control. The reduction in body weight corresponded with marked dose-dependent reductions in feed intake (Fig. 3) suggesting that the reduction in body weight of sirappac-treated animals may be a result of a loss of appetite in the animals. To further investigate this assertion, serum leptin levels were determined (Fig. 4). Food intake is controlled by hormones and the activities of the sympathetic nervous system. Leptin is one such hormone which regulates food intake. Circulating leptin levels are directly related to adipose tissue mass (Maffei et al., 1995). High leptin levels signal the presence of sufficient energy stores to sites in the central nervous system, which respond by reducing appetite and increasing energy expenditure, preventing severe obesity (Frederich et al., 1995). Decreasing circulating leptin levels as a result of increasing doses of sirappac treatment may therefore be an indication of low adipose tissue mass that should of essence increase appetite and subsequently feed intake. This however wasn't the case implying that sirappac may directly act to reduce appetite and in so doing fat circulation and thus, prevent fat deposition as energy stores in adipose tissue. Indeed, it was observed in this study that sirappac-treated animals were significantly leaner than the control (Fig. 2).

High levels of atherogenic lipids and low levels of non-atherogenic lipids in the blood have been reported to result in an increase in fat mass that leads to obesity in individuals, which eventually increases the risk for cardiovascular diseases (GirardMauduit, 2010), hypertension, diabetes, insomnia, chronic fatigue and early death (Patterson et al., 2004). Low density lipoprotein cholesterol has been labelled as bad cholesterol because it contains more fat and less protein that contributes immensely to plaque formation in blood vessels, resulting in cardiovascular diseases. The lowering of serum levels of atherogenic lipids such as LDLC, TC and $\mathrm{TG}$ while increasing levels of non-atherogenic lipids such as HDLC by sirappac (Figs. 7-8) may lead to the lowering of the risk of obesity and the onset of cardiovascular diseases. A high level of HDL is known to protect against atheroma development by removing VLDL and LDL from circulation back into the liver to be eliminated (Baron, 1982).

Reduction in blood pressure levels can reduce the incidence of heart disease by $15-20 \%$ and also the risk of heart attacks. The primary aim of anti-hypertensive drugs should be to lower elevated blood pressure levels to less than 140/90 $\mathrm{mmHg}$ (Shaw, 2009). Results of the blood pressure measurements from this study showed significant $(\mathrm{p}<0.05)$ reductions in systolic blood pressure by sirappac (Fig. 10). This could be as a result of its anti-dyslipidaemia activity which may prevent the accumulation and subsequent clogging and hardening of the arteries (atherosclerosis). This is further supported by the reductions in atherogenic indices (Fig. 9) by sirappac. The determination of atherogenic indices are very important means of assessing the risk of cardiovascular disease with high values being indicative of a higher risk of developing the disease (Dobiásová, 2004; Gaziano et al., 1997).

\section{CONCLUSION}

From the results obtained, it can be concluded that sirappac's reduction of body weight of rats may be through the suppression of appetite with subsequent reduction in fat uptake and 
deposition. The reduction of serum atherogenic lipid levels (TC, TG and LDLC) and elevation of non-atherogenic lipid (HDLC) levels with subsequent reduction in atherogenic indices may lead to reduction in elevated systolic blood pressure. This is an indication of the possible use of sirappac in the control of obesity and some major risk factors associated with cardiovascular disease.

\section{FINANCIAL SUPPORT AND SPONSORSHIP}

Nil.

\section{CONFLICTS OF INTEREST}

There are no conflicts of interest.

\section{ACKNOWLEDGEMENT}

The authors are grateful to the technical staff of the Animal Experimentation Unit of the Centre for Plant Medicine Research (CPMR) for their support and assistance.

\section{REFERENCES}

Mahalle N, Garg MK, Naik SS and Kulkarni MV. Study of pattern of dyslipidaemia and its correlation with cardiovascular risk factors in patients with proven coronary artery disease. Indian J Endocrinol Metab, 2014; 18:48-55.

Krukemyer JJ and Talbert RL. Lovastatan new cholesterol-lowering agent. Pharmacotherapy, 1987; 7:198-210.

Hebert PR, Gaziano JM, Chan KS and Hennekens CH. Cholesterol lowering with statin drugs, risk of stroke, and total mortality. An overview of randomized trials. JAMA, 1997; 4:313-321.

Reddy JK, Goel SK, Nemali MR, Carrino JJ, Laffler TG, Reddy MK, Sperbeck SJ, Osumi T, Hashimoto T, Lalwani ND and Rao MS: Transcription regulation of peroxisomal fatty acyl-CoA oxidase and enoyl-CoA hydratase/ 3-hydroxyacyl-CoA dehydrogenase in rat liver by peroxisome proliferators. Proc Natl Acad Sci, 1986; 83:1747-1751.

Watts GF and Dimmitt SB. Fibrates, dyslipoproteinaemia and cardiovascular disease. Curr Opin Lipidol, 1999; 10:561-574.

Asztalos BF, Horvath KV, McNamara JR, Roheim PS, Rubinstein JJ, Schaefer EJ. Comparing the effects of five different statins on the HDL subpopulation profiles of coronary heart disease patients. Atherosclerosis, 2002; 164:361-369.

Steinmetz KL. Colesevelam hydrochloride. Am J Health Syst Pharm, 2002; 59:932-939.

Ozawa $\mathrm{H}$ and Ozawa T. A 50-year history of new drugs in Japan: the developments of anti-tuberculosis drugs and their influences on the epidemiological aspects. Yakushigaku Zasshi, 2002; 37:84-94.

Kharbanda RK, Wallace S, Walton B, Donald A, Cross JM, Deanfield J. Systemic Acyl-CoA: cholesterol acyltransferase inhibition reduces inflammation and improves vascular function in hypercholesterolemia. Circulation, 2005; 111:804-807.

Ueshima K, Akihisa-Umeno H, Nagayoshi A, Takakura S, Matsuo M, Mutoh S. Implitapide, a microsomal triglyceride transfer protein inhibitor, reduces progression of atherosclerosis in apolipoprotein E knockout mice fed with a Western-type diet: involvement of the inhibition of postprandial triglyceride elevation. Biol Pharm Bull, 2005; 28:247-252.

Gauthier A, Lau P, Zha X, Milne R, McPherson R. Cholesteryl ester transfer protein directly mediates selective uptake of high density lipo- protein cholesteryl esters by the liver. Arterioscler Thromb Vasc Biol, 2005; 25:2177-2184.

Vasudevan AR and Jones PH. Effective use of combination lipid therapy. Curr Cardiol Rep, 2005; 7:471-479.

Danquah CA, Woode E and Boakye-Gyasi E. Anti-arthritic Effects of an Ethanolic Extract of C. erythrocarpus Isert Roots in Freund's Adjuvant-induced Arthritis in Rats. Journal of Pharmacology and Toxicology, 2011; 6:201-217.

Hutchinson, J. The Genera of Flowering Plants (Angiospermae) Dicotyledons. Vol, 2, Clarendon Press, London, 1967: 659.

Tlili N, Elfalleh W, Saadaoui E, Khaldi A, Triki S, Nasri N. The caper (Capparis L.): Ethnopharmacology, phytochemical and pharmacological properties. Fitoterapia, 2011; 82(2):93-101.

Viqar UA, Nargis I, Aziz AA. Isocodonocarpine from C. decidua. Phytochemistry, 1989; 28:2493-5.

Viqar UA, Nargis I, Shoib AMP, Shoib A, Aziz AA. Two new N-acetylated spermidine alkaloids from C. decidua. J Nat Prod 1992; 55:1509-12.

$\mathrm{Fu}$ XP, Wu T, Abdurahim M, Su Z, Hou XL, Aisa HA, et al. New spermidine alkaloids from C. spinosa roots. Phytochem Lett 2008; 1:59-62.

Lyaruu HVM, Kioangau DP, Hosea, KM and Cossan, CJ. Use of traditional medicines in the management of HIV/AIDS opportunistic infections in Tanzania: a case study in the Bukuba rural district. J. Ethnobiol. Ethnomed, 2007; 3: 29-42.

Martey ONK, Armah, GE, Sittie AA and Okine LKN. A chronic toxicity study of the ground root bark of $C$. erythrocarpus (Capparaceae) in male Sprague-Dawley rats. Pak J Biol Sci, 2013; 16:1706-1713.

Maffei M, Halaas J, Ravussin E, Pratley RE, Lee GH, Zhang Y., et al. Leptin levels in human and rodent: measurement of plasma leptin and RNA in obese and weight-reduced subjects. Nat Med, 1995; 1:1155-1161.

Frederich RC, Hamann A, Anderson S, Lollmann B, Lowell BB, Flier JS. Leptin levels reflect body lipid content in mice: evidence for diet-induced resistance to leptin action. Nat Med 1995; 1:1311-1314.

Girard-Mauduit, S. The lipid triad, or how to reduce residual cardiovascular risk. Annales d'Endocrinologie, 2010; 71:89-94.

Patterson RE, Frank LL., Kristal AR., White E, A comprehensive examination of health conditions associated with obesity in older adults, American Journal of Preventive Medicine, 2004, 27, 5:385-390.

Baron DN. A Short Textbook of Chemical Pathology. Suffolk, UK. Richard Clay Ltd, Bungay.

Shaw G. 2009. Pre-hypertension: Early-stage high blood pressure. [ONLINE] Available at: http://www.webmd.com/content/article/73/88927.htm. [Retrieved 03 July 2009].

Dobiásová M. Atherogenic Index of Plasma [log (triglyceride/ HDL-Cholesterol)]. Theoretical and Practical Implications. Clin Chem, 2004; 50:1113-1115.

Gaziano JM, Hennekens CH, O’Donnell CJ, Breslow JL, Buring JE. Fasting triglycerides, high-density lipoprotein, and risk of myocardial infarction. Circulation, 1997; 96:2520-2525.

How to cite this article:

Saka P, Osafo KE, Antwi S, Martey ONK, Quasie O, Antwi-Adjei M, Asiedu-Larbi J, Takyi NK, Donkor KN, Okine LKN. The Anti-dyslipidemic Effects of Milled Root Bark Ethanolic Extract of C. erythrocarpus in Sprague-Dawley Rats: Implications for Obesity and Cardiovascular Diseases. J App Pharm Sci, 2018; 8(01): 001-008. 